\title{
AKIBAT-AKIBAT HUKUM TERHADAP PELAKU TINDAK PIDANA PEMALSUAN REKAM MEDIS SESEORANG
}

\author{
Mario Gregorius Funan Ahoinnai, I Nyoman Sugiartha, I Made Minggu Widyantara \\ Fakultas Hukum Universitas Warmadewa, Denpasar - Bali, Indonesia
}

\begin{abstract}
Abstrak
Pelayanan kesehatan khususnya dalam dunia medis, pasien yang merasa bahwa pelayanan yang diberikan kurang memuaskan bahkan menyebabkan keadaan yang fatal hingga merugikan pasien yang disebabkan oleh kesalahan paramedis, maka keluarga pasien pasti melakukan upaya yang tegas, ditambah jika hak-hak pasien merasa tidak diberikan. Tujuan dari penelitian ini untuk mengetahui akibat hukum terhadap pemalsuan rekam medis asal-usul seseorang dan pertanggungjawaban dari rumah sakit yang turut serta membantu melakukan pemalsuan rekam medis. Pada penelitian ini menggunakan tipe penelitian hukum normatif dengan menganalisis serta mengetahui hukum menjadi perangkat peraturan sebuah norma positif dalam sistem perundang- undangan. Akibat hukum terhadap pemalsuan rekam medis asal-usul seseorang tidak diatur secara jelas pada peraturan yang berkaitan dengan pemalsuan rekam medis seseorang hal tersebut tidak diatur jelas dalam Wetboek van Statrecht (KUHP) namun rekam medis merupakan suatu dokumen rahasia dimana dalam hal terjadinya pemalsuan terhadap dokumen atau surat telah diatur didalam Pasal 263 KUHP yang secara tegas menghukum siapapun yang terbukti melakukan tindak pidana pemalsuan surat. Pertanggung jawaban dari rumah sakit yang turut memalsukan rekam medis adalah dilakukannya proses peradilan pidana untuk membuktikan unsur - unsur kesalahan dalam tindak pidana untuk dapat dipertanggung jawabkan karena telah diatur didalam Undang-Undang Nomor 36 Tahun 2014 tentang Tenaga Kesehatan yang termuat dalam pasal 84 yang berisi tindakan yang terjadi karena kelalaian yang dilakukan oleh dokter perawat ataupun tenaga Kesehatan.
\end{abstract}

Kata kunci Akibat Hukum, Pemalsuan, Rekam Medis.

\begin{abstract}
Health services especially in the medical world, patients who feel that the services provided are not satisfactory even cause fatal conditions to the detriment of patients caused by paramedic errors, then the patient's family must make a firm effort, plus if the patient's rights feel not given. The purpose of this study was to determine the legal consequences of falsification of medical records of the origin of a person and the responsibility of hospitals that participated in helping falsify medical records. In this study using the type of normative legal research by analyzing and knowing the law becomes a set of rules a positive norm in the legislation system. The legal consequences of falsifying a person's medical record are not clearly regulated in regulations relating to the falsification of a person's medical record, it is not clearly regulated in Wetboek van Statrecht (KUHP), but a medical record is a confidential document in the event of falsification of documents or a letter has been regulated in Article 263 of the Criminal Code which explicitly convicts anyone found guilty of falsifying a letter. The responsibility of the hospital which also falsified the medical record is a criminal justice process to prove the elements of wrongdoing in a criminal act to be accounted for because it has been regulated in Law Number 36 of 2014 concerning Health Workers contained in article 84 which contains actions which occurs due to negligence committed by a nurse doctor or health worker.
\end{abstract}

Keywords Legal Counterfeiting Medical Records.

\section{PENDAHULUAN}

Pada peradaban era sekarang ini yang terus mengalami perkembangan dan kemajuan yang pesat dengan seiring berbagai kecanggihan dan kemudahan dalam berbagai kebutuhan hidup yang mana terdapat penemuan-penemuan baru berupa penemuan baru dalam bidang teknologi budaya dan lingkungan sosialnya dengan demikian ini menjadi bukti bahwa memang perkembangan ini memiliki dampak yang berbeda pula. Secara khusus dalam penemuan teknologi baru sekarang ini teknologi sudah menjadi kebutuhan yang teramat penting bahkan tidak dapat dipisahkan dari kehidupan manusia serta 
keberadaannya merata di sektor kehidupan manusia. Besar dan pentingnya sebuah teknologi terhadap masyarakat Indonesia yang semakin banyak mengalami perubahan yang merupakan wujud dari modernisasi zaman dalam lingkungan sosial masyarakat terutama pada perkembangan teknologinya seperti halnya di dunia kedokteran. Bidang kedokteran sangat membutuhkan teknologi dalam penunjang tindakan medis yang akan dilakukan mengingat hal tersebut teknologi dibidang kedokteran memang harus terus berkembang semakin canggih guna memudahkan cara kerja para tim medis serta dokter (Machmud 2012).

Selain memperluas wawasan serta memudahkan aktivitas masyarakat di lingkungan sosial ini beragam kemajuan dan perkembangan didalam Ilmu Pengetahuan Teknologi (IT) yang juga memiliki pengaruh dengan upaya - upaya masyarakat demi mempertahankan keadaan kesehatan dan pelayanan kesehatan tersebut menjadi lebih baik. Pada dasarnya sejarah ilmu kedokteran telah dikenal sejak manusia mengenal hidup sosial berkelompok dan mengenal berbagai jenis penyakit yang timbul dimasyarakat atau kelompok manusia tersebut bahkan hingga cara pengobatannya. Pada zaman dahulu pengobatan pada penyakit hanyalah menggunakan obat-obatan alami atau herbal dan belum mengenal banyaknya obat-obatan kimiawi yang diracik dengan teknologi yang canggih yang sekarang ini beredar diberbagai rumah sakit hingga toko obat di berbagai super market.

Dengan berbagai kemajuan dikalangan masyarakat hingga masa sekarang ini masyarakat makin banyak mendapat pengetahuan dan kemudahan serta dapat meningkatkan kesadaran yang cukup terhadap hal - hal yang berlaku di Indonesia terutama terhadap hukum yang berlaku di masyarakat tentang kesehatan dengan demikian pasien atau keluarga pasien diberi kemudahan guna mendapat kesehatan dan pelayanan kesehatan yang memuaskan.

Pelayanan kesehatan khususnya dalam dunia medis kesehatan pastinya akan mengalami beberapa kekurangan dalam pelayanan pasien atau keluarga pasien yang merasa dirugikan atau mendapat dampak atas tindakan yang merugikan dari paramedis yang menyebabkan kerugian yang mana hal tersebut dilakukan oleh pada paramedis pasien atau keluarga pasien pasti akan melakukan tindakan yang tegas jika hak - hak pasien tersebut merasa tidak dilayani sesuai standar yang berlaku bahkan tidak diberikannya sama sekali dengan demikian pasien atau keluarga pasien yang merasa demikian serta memiliki pemahaman yang cukup tentang hukum yang mengatur tentang kesehatan pastinya akan membuat gugatan ke Pengadilan terhadap sarana pelayanan kesehatan maupun kepada tenaga kesehatan yang memberi pelayanan. Mendapatkan keadilan perlindungan serta kepastian hukum yang tegas bagi pihak - pihak tersebut dan harus diproses secara hukum yang berlaku (Triwibowo 2004).

Keadaan yang menyebabkan kerugian tersebut tidak mutlak dapat menjamin terkabulnya tuntutan dari pihak pasien atau keluarga pasien secara penuh atau sebaliknya dari itu bahkan membebaskan pihak terkait tenaga kesehatan dokter perawat - perawat maupun sarana pelayanan kesehatan yang dalam hal ini sebagai pihak tergugat dari apapun tuntutan hukumnya. Hukum yang mengatur dalam lembaga kesehatan merupakan sebuah unsur yang secara khusus memiliki standar aturan atau pedoman terhadap pengelolaan rumah sakit tenaga medis maupun sarana kesehatan yang dimiliki disebuah rumah sakit tersebut.

Pemeriksaan kasus pemalsuan terhadap rekam medis oleh tim medis memiliki beberapa tahapan penyelesaian mulai dari dikepolisian penyelidikan penyidikan penuntutan serta pemeriksaan perkara oleh pengadilan untuk membuktikan terdapat kesalahan atau tidak dalam tindakan yang dilakukan oleh paramedis atau tenaga kesehatan maupun sarana pelayanan kesehatan tempat mereka bekerja. Pemalsuan rekam medis oleh tenaga kesehatan ataupun sarana pelayanan kesehatan tempat mereka bekerja dalam dugaan kasus pemalsuan rekam medis tersebut rekam medis pasien tersebut dapat diajukan di pengadilan sebagai salah satu sumber bahan atau alat bukti yang tertulis yang dapat diteliti dan dikembangkan namun rekam medis ini juga dapat diuji oleh tim ahli yang menangani bidang tersebut guna mengetahui letak pemalsuan yang dilakukan oleh dokter ataupun para petugas medis.

Rekam medis memiliki kekuatan yang sama dengan alat bukti surat karena rekam medis merupakan dokumen atau surat hasil pemeriksaan kesehatan yang bersifat rahasia yang hanya diketahui oleh dokter perawat maupun tenaga medis lainnya dan rekam medis memiliki keabsahan yang sama dengan alat bukti surat. Rekam medis bersifat rahasia karena isi dalam rekam medis termuat identitas pasien serta riwayat penyakit yang dialami oleh pasien. Rekam medis pada dasarnya sangat memiliki pengaruh bagi keberlangsungan hidup pasien dan kelurga pasien karena rekam medis berisi data penting dan tidak hanya itu dikeluarkannya rekam medis harus sesuai standar dan harus dengan keadaan 
yang sebenarnya apabila rekam medis tersebut dibuat palsu maka akan membuat dampak buruk terhadap pasien.

Dari uraian latar belakang diatas dapat dirumuskan dua pokok rumusan masalah yaitu Bagaimana akibat hukum terhadap pemalsuan rekam medis asal-asul seseorang dan Bagaimana pertanggungjawaban dari rumah sakit yang turut serta membantu melakukan pemalsuan rekam medis. Tujuan dari penelitian ini untuk mengetahui akibat hukum terhadap pemalsuan rekam medis asal-usul seseorang dan pertanggungjawaban dari rumah sakit yang turut serta membantu melakukan pemalsuan rekam medis.

\section{METODE PENELITIAN}

Pada tipe penelitian ini penulis menggunakan tipe penelitian hukum normatif, yaitu dengan mengkaji atau menganalisis dengan memahami hukum sebagai perangkat peraturan dan/atau normanorma positif di dalam sistem perundang-undangan yang mengatur mengenai kehidupan manusia (Soekanto 1986). Pendekatan penulisan yang digunakan dalam penulisan ini adalah pendekatan perundang-undangan (statute approach) dan pendekatan konseptual (conceptual approach). Sumber bahan hukum dalam penelitian ini berupa bahan hukum primer dan bahan hukum sekunder, yang mana sumber bahan ini berkaitan dengan rumusan masalah diatas. Teknik Pengumpulan bahan hukum primer dan sekunder dikumpukan dengan teknik studi kepustakaan dan studi dokumentasi. Bahan-bahan hukum yang telah diperoleh dari kepustakaan baik berupa konsep-konsep hukum maupun peraturan perundangundangan akan diolah dengan metode deduktif dan induktif dan/atau pengurutan sehingga mudah dapat dibaca serta dipahami.

\section{III. HASIL PENELITIAN DAN PEMBAHASAN}

\section{Akibat-Akibat Hukum Terhadap Pemalsuan Rekam Medis Asal-Usul Seseorang}

Menurut Edna K. Huffman rekam medis adalah kompilasi (ringkasan terarah) fakta-fakta sejarah kehidupan dan Kesehatan pasien, termasuk penyakit lama dan penyakit sekarang dan pengobatannya, ditulis oleh professional Kesehatan yang ikut merawat pasien tersebut (Sabarguna 2004). Penyelenggaraan rekam medis secara tidak langsung harus dapat mempertanggungjawabkan segala kehilangan, kerusakan, pemalsuan, dan/atau penggunaan oleh orang atau badan yang tidak berhak terhadap rekam medis yang dibuat tersebut (Ratman 2018).

Akibat hukum dari pemalsuan rekam medis sebenarnya berkaitan erat dengan tujuan peran dan fungsi dari adanya rekam medis tersebut. Rekam medis yang memiliki tujuan untuk memberikan perlindungan dan kepastian hukum yang tidak hanya dari aspek administrasi ataupun aspek medis namun yang paling terpenting dari keseluruhan aspek hukum tersebut yakni terkait dengan kedudukan rekam medis. Kedudukan rekam medis dapat dijadikan sebagai alat bukti dalam proses persidangan apabila rekam medis ini dibutuhkan keabsahannya yang mana sesuai dengan KUHAP (Kitab UndangUndang Hukum Acara Pidana) pasal 184 ayat (1) huruf c rekam medis yang dapat sebagai alat bukti dalam perkara pidana dan pasal $164 \mathrm{HIR}$ rekam medis bisa menjadi alat bukti tertulis dalam perkara perdata namun dalam aspek medis untuk mengukur tindakan - tindakan medis yang dilakukan oleh dokter atau tim medis telah melakukan tindakan sesuai Standar Profesi Medis (SPM) yang telah diketahui oleh paramedis hal ini dikarenakan apabila dalam isi rekam medis tersebut termuat beberapa atau keseluruhan isi yang diubah atau dibuat menjadi tidak sama dengan tindakan medis yang dilakukan oleh dokter atau tim medis maka akan memberi efek tidak baik dalam keberlangsungan hidup pasien itu sendiri bahkan hingga membuat perselisihan antar keluarga pasien sehingga dengan ini bisa diduga telah terjadinya perbuatan yang melanggar malpraktek dan dengan adanya hal tersebut dapat dilakukan upaya hukum hukum baik secara jalur perdata pidana maupun administrasi dengan jelasnya pengaturan yang mengatur tentang pemalsuan rekam medis ini akan memberi kejelasan dan perlindungan hukum bagi pasien keluarga pasien maupun masyarakat yang merasa dirugikan oleh dokter maupun tenaga medis yang menyebabkan hal tersebut terjadi.

Palsu atau keadaan yang tidak benar dari suatu isi dalam tulisan maupun berita yang diucapkan atau disebarkan bahkan ditulis dapat membawa dampak pengaruh terhadap aspek kehidupan seseorang. Isi tulisan atau berita dalam keadaan tertentu atau dengan syarat - syarat tertentu tidak boleh mengandung sifat palsu. Sifat palsu dari isi sebuah tulisan atau berita yang mengandung pengaruh buruk 
itulah yang sebenarnya perlu dihindari dengan cara mengancam pidana perbuatan yang membuat (Adami 2007).

Demikian halnya dalam membuat rekam medis seseorang haruslah dibuat dengan keadaan sebenarnya dan disampaikan dengan jelas dan tidak ada sifat palsu yang termuat didalamnya yang mengakibatkan hal - hal yang dapat merugikan banyak pihak. Rekam medis merupakan sebagai catatan dalam praktek kedokteran yang telah dikenal sejak zaman palaeplitikum (zaman batu). Pada masa tersebut rekam medis dituliskan pada gua batu. Penemuan mengenai catatan tentang pengobatan banyak ditemukan pada dinding - dinding gua atau tercatat pada lembaran kayu atau dibatu-batu dengan bidang datar pada zaman Mesir Kuno Yunani dan Romawi. Rekam medis dapat dikatakan sebagai dokumen yang bersifat rahasia karena berdasarkan Undang-Undang nomor 13 tahun 1985 tentang Bea Materai. Dalam hal tersebut yang menyatakan bahwa dokumen merupakan kertas (berkas) yang didalamnya mengandung tulisan - tulisan yang berisikan tentang kenyataan keadaan ataupun perbuatan. Rekam medis yakni dokumen yang berisikan catatan dan dokumen tentang identitas pasien pemeriksa pengobatan tindakan dan pelayanan lainnya yang diberikan oleh pihak rumah sakit kepada pasien selama menjalani maupun setelah melakukan tindakan dengan menjadikan rekam medis tersebut sebagai suatu sarana pelayanan kesehatan yang mana catatan atau rekam medis ini bersifat dokumen rahasia dan hanya diketahui oleh dokter dan pasien (Ratman 2018).

Di setiap sarana prasarana pelayanan terhadap kesehatan dalam mempertahankan dan meningkatkan kualitas pelayanan profesional untuk itu dengan melengkapi kebutuhan informasi atau informed concent locum tenensdemi kepentingan dokter pengganti yang meneruskan menjalankan perawatan pasien dengan hal tersebut diperlukannya catatan rekam medis karena adanya hak untuk merawat pasien. Dapat dilihat dari keadaan masyarakat yang masih belum terbiasa secara aktif mencari dan mendapatkan informasi dalam penggunaan pelayanan medis secara mudah lengkap dan terperinci sering terjadinya kesalahan baik secara penyampaian maupun tanggapan yang dipikirkan oleh pasien itu sendiri dengan penyampaian informasi dari pasien maupun keluarga pasien mengenai hasil dari tindakan yang telah dijalaninya bahkan mengenai rekam medis DNA atau (asam deoksiribonukleat). Seorang pasien yang menjalani perawatan atau pasien yang meminta keterangan DNA atau (asam deoksiribonukleat) disuatu sarana pelayanan kesehatan di instansi kesehatan berhak untuk mengetahui penyakit yang diderita hasil Tindakan ataupun penjelasan-penjelasan yang murni dan tidak ada yang dirahasiakan ataupun dipalsukan dari dokter tersebut. Namun pada kenyataannya pasien dan keluarga pasien kerap mengalami kerugian akibat tindakan yang dianggap kelalaian kesalahan atau kurang mampunya dokter dalam penyampaian rekam medis yang mengakibatkan kekeliruan tersebut terjadi dan berdampak pula bagi pasien maupun pihak keluarga.

\section{Pertanggungjawaban Dari Pihak Rumah Sakit Yang Membantu Melakukan Pemalsuan Rekam Medis}

Penyelenggaraan rekam medis harus tegas diatur dan ditata sedemikian rupa sesuai dengan peraturanperaturan dalam penyelenggaraan rekam medis tersebut agar data - data pasien yang terkandung dan termuat di dalam rekam medis dapat dijaga kerahasiaannya dan oleh karena itu dengan dijaga kerahasiaannya dapat dipertanggung jawabkan kebenarannya oleh karena itu setiap pemimpin sarana pelayanan kesehatan sangat harus memerhatikan dengan teliti terhadap penyelenggaraan rekam medis tersebut. Kewajiban pihak rumah sakit dalam memberikan menunjang sarana atau fasilitas pelayanan medis dengan standar profesi serta standar operasional dan juga kebutuhan medis pasien sebelum selama dan setelah perawatan yaitu dengan memenuhi kewajiban dokter dan tim medis dalam memberikan pelayanan medis yang terbaik berupa pelayanan kesehatan maupun pelayanan administrasi medis secara khusus penyelenggaraan rekam medis yang sesuai dengan 3 kewajiban utama.

Sifat ketiga kewajiban ini merupakan kumulatif yang mana standar profesi ialah kemampuan dasar atau wajib yang dikuasai oleh seseorang atau seorang dokter guna untuk kegiatan yang professional kepada masyarakat secara mandiri yang dalam hal ini dibuat oleh organisasi profesi. Standar prosedur operasional adalah suatu perangkat instruksi atau langkah-langkah yang dibuat untuk menyelesaikan pekerjaan dari dokter maupun tim medis.

Standar prosedur professional dalam melaksanakan berbagai kegiatan dan fungsi pelayanan kesehatan yang berdasarkan pada standar profesi dengan melihat secara rinci dari beberapa aspekaspek penting yang mana rekam medis mempunyai kegunaan yang sangatlah luas karena rekam medis tidak hanya mengenai data pasien dan keterkaitan antara pasien dengan pemberi pelayanan namun 
adapun kegunaan rekam medis secara umum ialah sebagai alat komunikasi yang jelas antara dokter dengan tenaga ahli lainnya yang ambil bagian dalam memberikan pelayanan-pelayanan pengobatan perawatan secara efisien kepada pasien dan sebagai dasar dan tujuan untuk merencanakan pengobatan serta perawatan kepada pasien yang harus diberikan kepada seorang pasien serta sebagai bukti tertulis atas segala tindakan pelayanan dirumah sakit baik perkembangan penyakit dan pengobatan selama pasien berkunjung dan sampai dirawat dirumah sakit maka dokter akan mengeluarkan rekam medis pasien dan akan menjelaskan mengenai apa yang menjadi keluhan pasien atau riwayat penyakit dari pasien itu sendiri.

Rekam medis sebagai bahan yang berguna untuk menjadi analisa penelitian dan evaluasi terhadap kualitas pelayanan maupun tindakan yang diberikan kepada pasien. Rekam medis tersebut bersifat rahasia demi melindungi kepentingan hukum pasien dan keluarga pasien rumah sakit maupun dokter dan tenaga kesehatan lainnya tidak memiliki kewenangan memberikan rekam medis kepada orang lain. Kepentingan kerahasiaan pasien harus menjadi tujuan utama dari penyelenggaraan pelayanan medis yang diberikan tenaga medis baik berupa pelayanan medis maupun dari segi pelayanan kesehatan lainnya. Dokter tidak dapat dibenarkan apabila dalam hal pemilihan metode pelayanan semata - mata hanya berdasarkan pertimbangan pada pembayaran prestasi langkah yang diambil oleh dokter harus sesuai pada langkah - langkah yang mengandung resiko yang paling kecil hingga paling sedikit dari semua kemungkinan resiko yang bisa terjadi dalam menjalankan tugasnya (Adami and Ardi 2015).

Bahwa rekam medis dapat diartikan dalam arti sempit dan arti luas. Rekam medis dalam arti sempit rekam medis hanya sebagai pencatatan dokumen atau perekaman dari data identitas pasien dan semua pemeriksaan tindakan riwayat pada pasien selama berobat ditempat pelayanan kesehatan sedangkan rekam medis yang memiliki pengertian atau arti yang luas yakni tidak hanya sekedar kegiatan pencatatan atau rekaman yang ditulis saja akan tetapi mempunyai pengertian sebagai suatu sistem penyelenggaraan rekam medis disuatu instansi atau unit kegiatan dalam upaya peningkatan unit rumah sakit itu sendiri.

Sedangkan kegiatan pencatatan itu hanya merupakan salah satu bentuk kegiatan yang tercantum dalam penerapan tugas yang dimulai pada saat diterimanya pasien dirumah sakit tersebut dan dilanjutkan hingga dengan perawatan pasien berdasarkan hasil dari rekam medis yang meliputi penyelenggaraan penyimpanan serta pengeluaran berkas dari tempat penyimpanan untuk melayani permintaan atau pinjaman apabila dari pasien atau untuk keperluan lainnya. Dasar hukum penyelenggaraan rekam medis dalam pelayanan kesehatan bagi pasien termuat dalam beberapa dasar hukum atau peraturan-peraturan yang mengatur penyelenggaraan rekam medis. Landasan hukum yang mendasari penyelenggaraan rekam medis di Indonesia yakni terdapat pada Undang-Undang Kesehatan Nomor 23 Tahun 1992 tentang Kesehatan.

Tanggungjawab terhadap rekam medis paramedis dalam penyelenggaraan rekam medis dengan melengkapi data pasien yang dirawatnya serta merahasiakan isi berkas rekam medis penandatanganan dan penulisan nama secara jelas melaksanakan informed consent dan dilarang melakukan penghapusan jejak pencatatan rekam medis adapun yang menjadi hubungan hukum antara dokter dan pasien yang membuat hak dan kewajiban hukum para pihak secara umum yang berlaku bagi dokter pasien maupun keluarga pasien walaupun hal demikian tidak dibuat secara formal yang jelas tertulis.

Pemenuhan kewajiban serta hak yang harus diberikan secara hukum oleh dokter maupun tenaga paramedisnya. Bagi dokter maupun paramedis akan mendapat sanksi berupa sanksi yang ringan sampai dengan sanksi yang berat yang bersifat moral kemasyarakatan sampai hukum administrasi perdata maupun pidana kewajiban dan tanggung jawab dokter dan paramedis secara umum pada kedokteran telah dipahaminya mengenai apa saja yang menjadi standar profesi medis dan standar operasional pelayanan kesehatan dirumah sakit.

\section{SIMPULAN DAN SARAN}

\section{Simpulan}

Akibat hukum terhadap pemalsuan rekam medis asal-usul seseorang tidak diatur secara jelas pada peraturan yang berkaitan dengan pemalsuan rekam medis seseorang hal tersebut tidak diatur jelas dalam Wetboek van Statrecht (KUHP) namun rekam medis merupakan suatu dokumen rahasia dimana dalam hal terjadinya pemalsuan terhadap dokumen atau surat telah diatur didalam Pasal 263 KUHP yang secara tegas menghukum siapapun yang terbukti melakukan tindak pidana pemalsuan surat sehingga dalam pasal ini menjadi menjadi payung hukum atas pertanggungjawaban pidana pemalsuan rekam 
medis meskipun tidak diatur secara tegas disebutkan dikarenakan mengingat rekam medis merupakan suatu berkas atau dokumen selain itu dalam Pasal 14 PERMENKES disebutkan bahwa pimpinan (direktur) rumah sakit yang harus memberikan pertanggungjawaban apabila terjadi suatu tindak pidana pemalsuan rekam medis hal ini menjadi tidak jelas siapa yang seharusnya bertanggung jawab dalam tindak pidana ini.

Pertanggungjawaban pidana terhadap rekam medis yang dipalsukan apabila pemalsuan rekam medis dapat dilakukan apabila tenaga medis tersebut terbukti membuat dan/atau merubah isi dari rekam medis sesuai dengan ketentuan pasal pemalsuan surat perlu dilakukannya proses peradilan pidana untuk membuktikan unsur - unsur kesalahan dalam tindak pidana untuk dapat dipertanggung jawabkan karena telah diatur didalam Undang-Undang Nomor 36 Tahun 2014 tentang Tenaga Kesehatan yang termuat dalam pasal 84 yang berisi tindakan yang terjadi karena kelalaian yang dilakukan oleh dokter perawat ataupun tenaga Kesehatan sehingga menyebabkan kecacatan atau kematian kepada penerima pelayanan secara perdata apabila dokter memenuhi unsur - unsur sah kelalaian maka dapat diajukannya gugatan perdata terhadap malpraktek.

\section{Saran}

Pemerintah perlu melakukan gerakan atau tindakan dalam rangka mengoptimalkan dan meningkatkan peraturan - peraturan yang terkait terutama mengenai perlindungan pasien dan keluarga pasien tentunya masalah pemalsuan rekam medis seseorang yang mana peraturan - peraturan atau payung hukumnya tidak kuat dan dari segi tenaga kesehatan atau paramedis lebih efektif dan lebih efisien guna mengurangi kerugian atau tindakan yang tidak diinginkan oleh pasien dan keluarga pasien yang dialami oleh pasien itu sendiri. Karena dampak dari adanya pemalsuan rekam medis tersebut membawa dampak yang fatal apabila rekam medis tersebut tidak sesuai dengan apa yang menjadi dasar atau acuan dari pemeriksaan pasien dirumah sakit.

Masyarakat hendaknya lebih berhati-hati dan teliti dalam mengambil tindakan apapun itu baik selaku pasien sebelum menerima rekam medis terlebih dahulu mencermati dan menanyakan kepada yang berwajib mengenai apa yang termuat didalam isi dari rekam medis itu sendiri agar nantinya saat rekam medis telah diterima dikemudian hari tidak terjadi kesalahan yang fatal serta mengakibatkan kerugian yang mengakibatkan palsunya sebuah rekam medis sehingga keadaan yang sebenarnya menjadi tidak jelas. Masyarakat perlu melakukan tindakan yang tegas apabila terjadi keadaan atau tindakan yang kurang baik dalam penanganan atau pelayanan kesehatan bagi masyarakat itu sendiri baik itu melalui kritikan langsung ataupun dapat dilakukan upaya hukum melalui jalur - jalur yang telah disediakan oleh pemerintah untuk melaporkan kerugian yang dialami pasien tersebut.

\section{DAFTAR PUSTAKA}

Adami, Chazawi and Ferdian Ardi. 2015. Tindak Pidana Pemalsuan Tindak Pidana Yang Menyerang Kepentingan Hukum Terhadap Kepercayaan Masyarakat Mengenai Kebenaran Isi Tulisan Dan Berita Yang Disampaikan. Edisi I. Jakarta: Rajawali Pers.

Adami, Chazawi H. 2007. Malpraktek Kedokteran Tinjauan Norma Dan Doktrin Hukum. Cetakan I. Malang: Banyumedia Publishing.

Machmud, H. Syahrul. 2012. Penegakan Hukum Dan Perlindungan Hukum Bagi Dokter Yang Diduga Melakukan Medikal Malpraktek. Bandung.

Ratman, H. Desriza. 2018. Aspek Hukum Informedconsent Dan Rekam Medis Dalam Transaksi Terapeutik. Edisi Kedu. Bandung: CV. Keni Media.

Sabarguna, B. S. 2004. Quality Assurance Pelayanan Rumah Sakit. Edisi Kedu. Yogyakarta: Konsorrsium rumah sakit islam Jateng-DIY.

Soekanto, Soerjono. 1986. Pengantar Penelitian Hukum. Jakarta: Universitas Indonesia Press.

Triwibowo, Cecep. 2004. Etika Dan Hukum Kesehatan. Yogyakarta: Nuha Medika. 